This item was submitted to Loughborough's Research Repository by the author.

Items in Figshare are protected by copyright, with all rights reserved, unless otherwise indicated.

\title{
Livelihoods in motion: linking transport, mobility and income-generating activities
}

PLEASE CITE THE PUBLISHED VERSION

https://doi.org/10.1016/j.jtrangeo.2016.06.020

PUBLISHER

(C) Elsevier

VERSION

AM (Accepted Manuscript)

\section{PUBLISHER STATEMENT}

This work is made available according to the conditions of the Creative Commons Attribution-NonCommercialNoDerivatives 4.0 International (CC BY-NC-ND 4.0) licence. Full details of this licence are available at: https://creativecommons.org/licenses/by-nc-nd/4.0/

\section{LICENCE}

CC BY-NC-ND 4.0

\section{REPOSITORY RECORD}

Esson, James, Katherine Gough, David Simon, Ebenchief Amankwaa, Olivier Ninot, and Paul W.K. Yankson. 2019. "Livelihoods in Motion: Linking Transport, Mobility and Income-generating Activities". figshare. https://hdl.handle.net/2134/20664. 
Esson, J., Gough, K.V., Simon, D., Amankwaa, E.F., Ninot, O., Yankson, P.W., 2016.

Livelihoods in motion: linking transport, mobility and income-generating activities.

Journal of Transport Geography.

Version: Accepted for publication 


\section{Abstract:}

During the past decade, there has been an increased focus on mobility in the social sciences linked to the so-called 'mobility turn', which claims that as mobility is so pervasive it should not be viewed as a rupture in society but as a normal way of life. This is certainly the case in urban contexts of sub-Saharan Africa where mobility forms an integral part of livelihood and income-generating activities. Drawing on in-depth qualitative research conducted in Accra, the capital of Ghana, this paper explores the mobility of urban residents in differing parts of the city in relation to their livelihood strategies. Through illustrating the ways in which the mobility of urban residents is aided or hindered by Accra's transport system, and by examining how this in turn influences their livelihood strategies, the paper contributes to an alternative new mobilities paradigm that is more considerate of, and builds upon insights from, the global South where such research has a longer pedigree than in the global North.

Keywords: livelihoods, mobility, transport, urban, Accra, Ghana

\section{Acknowledgements:}

This research is part of the 'African Rural-City Connections' (RurbanAfrica) research project. RurbanAfrica is funded by the European Union under the 7th Research Framework Programme (theme SSH), Grant Agreement no. 290732. More information can be found at: http://rurbanafrica.ku.dk/. In the field Mr Peter Mensah from the University of Ghana provided outstanding research assistance. 


\section{Introduction}

Mobility has both spatial and temporal dimensions, existing in a 'myriad of forms' and at a range of scales from the local to the global (De Bruijn et al. 2001). Contemporary debates over mobility are primarily framed within the so-called 'mobility turn', which claims that mobility is so widespread that it should not be seen as a rupture in society but as a normal way of life, with immobility being the anomaly (Sheller \& Urry 2006). Central to the mobility turn is a reassertion of cultural values that focus on technological advances and new ways of living. A key rationale behind this move is the assertion by mobility turn advocates that social scientists had previously ignored mobility's socio-cultural dimensions. Yet, while this proclamation may be true in a global North context, it appears less valid in the global South. With the exception of very economistic or technical planning studies, scholars working in the global South have long devoted attention to motives for and the impact of migration and mobility on domestic life, social cohesion and indigenous values. In sub-Saharan Africa, for example, mobility and migration have formed enduring research foci since the 1950s, with the analytical lenses deployed changing over time to reflect theoretical or ideological innovation on the one hand, and shifting policy and planning concerns on the other (see for example, Fields 1975; Mabogunje 1990; Porter et al. 2012; Simon 1986).

As part of efforts to provide a more nuanced academic debate, scholars have begun to sketch out an alternative new mobilities paradigm that is more considerate of, and builds upon insights from, the global South (Langevang \& Gough 2009; Lombard \& Ninot 2010; Pirie 2009a; Rigg \& Salamanca 2011). A key aspect of this work is addressing concerns that the reaffirmation of cultural values as part of the mobility turn is often divorced from the material base of people's lives. This point is clearly articulated in Rigg's (2007) call for mobility to be examined in relation to livelihoods. Importantly, the relationships between mobility and livelihoods in these discussions are framed beyond the confines of the dominant livelihoods framework and its five forms of capital (human, social, physical, natural and financial). Although the livelihoods framework has several merits, it overlooks how transforming structures and power relations interact with livelihoods to impact on issues of social inclusion and exclusion, both temporally and spatially (De Haan \& Zoomers 2005; King 2011).

This paper contributes to the emerging alternative new mobilities paradigm by demonstrating the potential of a more holistic approach that considers the intersections of urban transport, mobility and livelihoods. A process-orientation lens is adopted, which enables an examination of 'the interrelationships of movements of people, objects, capital and ideas in and through the overlapping scales of the local, the body, the national and the global' (Oswin \& Yeoh 2010, p.170). This allows the city to be envisaged as 'a mobile networked whole - 
messy, moving and morphing - rather than as compartmentalised sections' (Skelton \& Gough 2013, p.460). Additionally, the paper responds to concerns that recent work associated with the mobility turn has failed to engage with transport geography (Shaw \& Hesse 2010). It does so by extending an understanding of both the systemic features of intra-urban transport structures and operations, and the perceptions, attitudes and oftenflexible livelihood-related decisions made by individual transport users.

The holistic approach outlined above is operationalised in relation to people living and working in Accra, Ghana's capital and largest city. Livelihood-related mobility is explored in the context of rapid urban growth, increasing mean incomes as the Ghanaian economy experiences renewed growth (partly linked to new offshore oil extraction), and deregulation of the transport sector. Following an outline of Accra's transport system in the next section, the methodological approach adopted is presented prior to a discussion of how different livelihood strategies entail varying degrees of mobility which in turn are influenced by residents' perceptions of, and interactions with, Accra's transport system.

\section{Accra's transport system}

Since the mid-1990s, the government's key policy objective for Ghana's transport sector has been to 'establish an efficient and modally complementary and integrated transport network for the movement of people and goods at least cost' (Kwakye \& Fouracre 1998, p.2).

Achieving this objective has proven difficult in Accra because the city is changing demographically and expanding spatially into its peripheral areas without the benefit of systematic planning (Gough \& Yankson 2012). To put this in context, the population of the Greater Accra Metropolitan Area (GAMA) increased from 2.6 million in 2002 (Armah et al. 2010), to an estimated 3.7 million inhabitants in 2010 (Agyemang 2015). Similarly, the urban area expanded from $555 \mathrm{~km}^{2}$, with $196 \mathrm{~km}^{2}$ in a state of transition in 2002 (Møller-Jensen et al. 2012), to covering over $1000 \mathrm{~km}^{2}$ of land in 2010 (Abane 2011). These processes of urban change have been accompanied by extended periods of underinvestment in the city's transport infrastructure, especially during the era of structural adjustment from the early 1980s to mid-1990s (Edward 1996). The situation has become more complex in recent years as new districts have been created within GAMA and the area under the jurisdiction of Accra Metropolitan Assembly (AMA) has decreased, with the consequence that there is no city level planning authority (personal communication, planning officer, 4.11.15). The result is a city that has strong functional interaction between the periphery and key commercial and administrative hubs located in the centre (Møller-Jensen et al. 2012), but which lacks a transport system capable of taking people and goods safely, quickly and affordably across its urban terrain. 
Armah et al. (2010) estimate that on a typical weekday, 270,000 vehicle trips are made in and out of Accra's Central Business District (see Figure 1), an estimated 1.3 million passenger trips enter or leave the Accra Ring Road, and 1.6 million passenger trips go into or out of the area within the motorway extension (Oteng-Ababio \& Agyemang 2012).

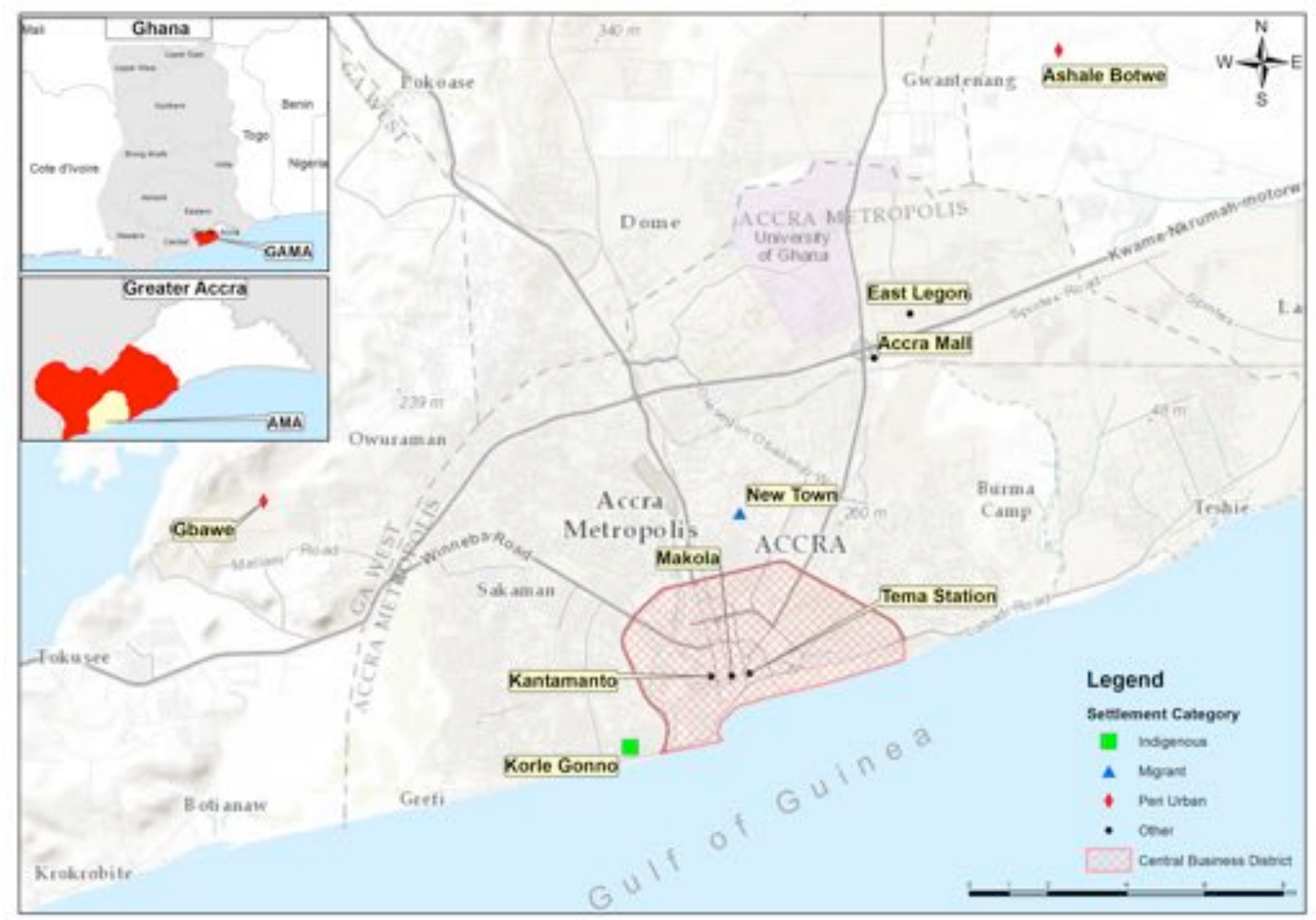

Fig 1: Map of Accra

Although some residents make use of non-motorized modes of transport, such as fourwheeled trolleys especially within the densely populated commercial districts (Amponsah et al. 1996), the numbers above exemplify Accra's status as a highly motor vehicle dependent city. This situation has been fuelled by a combination of spatial planning, an infrastructure investment strategy that favours arterial road expansion (Obeng-Odoom 2013), and a lack of alternative non-road based public transport resulting in severe traffic congestion that extends beyond the morning and evening peaks. This motor vehicle dependence is causing considerable air and noise pollution (Armah et al. 2010) and contributed to 8,561 pedestrian road traffic accidents in Accra between 2004 and 2010 (Aidoo et al. 2013). Given that economic liberalization has resulted in the current rate of vehicle importation into Ghana being three times higher than the national population growth rate, this situation is likely to continue. Private car ownership, however, remains the preserve of higher income groups 
with the vehicular population being just under one million for a human population of 23 million (Obeng-Odoom 2010).

The lack of investment in non-road based public transport is evident in the conspicuous absence of passenger train services. Ghana's rail network, which is approximately $950 \mathrm{~km}$ in length, has been the subject of several high profile government-backed restoration projects (Dinye 2012). Yet, despite this pro-rail policy rhetoric, the network currently primarily serves freight, and public usage in Accra is virtually non-existent. Meanwhile the city has witnessed considerable capital-intensive, aid-supported upgrading and arterial road expansion programmes. The most substantial of these is currently nearing completion and embraces an enhanced ring and radial highway system linked to upgrades of the principal intercity routes to which they are connected. In association with this is the country's first major retail mall (Accra Mall) adjacent to Tetteh Quarshie interchange (formerly Circle) at the intersection of two of these arteries in East Legon, and itself instantly the source of major traffic congestion since opening in 2008 (Obeng-Odoom 2013).

The Ministry for Transport has overall responsibility for infrastructure delivery and transport policy development in Accra, however, according to the Local Government Act (No.462 of 1993), urban passenger transport is a responsibility devolved to the Metropolitan, Municipal or District Assembly covering the locality in question (Finn et al. 2009). Despite their legal mandate to oversee the provision of urban passenger transport services, the local assemblies have made few interventions within the transport sector because their devolved responsibilities have not been accompanied by a corresponding diffusion of sufficient power and resources (Kumar \& Barrett 2008). Local assemblies, for example, have little to no control over the management of parastatal entities, such as Metro Mass Transit Ltd (MMT), and had minimal involvement in the unsuccessful pilot Bus Rapid Transport system between 2005 and 2007 (Agyemang 2015). They do, however, have limited influence over the operation of the commercial minibuses - colloquially known as tro-tros - being responsible for the licensing of drivers but otherwise not interfering in the service delivery. The tro-tro service is primarily self-regulating with operators unionized into powerful groups, most notably the Ghana Private Road Transport Union (GPRTU), which also oversees inter-urban passenger transport services (Finn 2008).

Tro-tros fill the void which exists due to the mismanagement, collapse and unsuccessful privatization of public transport operations (Fouracre et al. 1994). Approximately 12,000 minibuses were registered in Greater Accra in 2005, around half of which were estimated to operate daily in the tro-tro sector, the remainder being either vehicles not scheduled to work 
or buses for private hire (Finn 2008). With each tro-tro capable of carrying 12 -15 passengers, they account for just under two-thirds of all trips made by public transport in the capital (Oteng-Ababio \& Agyemang 2012). The attractiveness of the tro-tro system lies in its' ability to be relatively flexible, the creative use of alternative road spaces during peak hours, and the proclivity to allow passengers to embark or disembark at locations of their choice, despite doing so being illegal. Customers complain, however, of poor vehicle conditions and lax safety standards (Amoh-Gyimah \& Aidoo 2013), and claim that operators increase their fares and alter their routes arbitrarily during peak-hour journeys to maximise profits (Agyemang 2015).

A popular alternative to tro-tros are shared and chartered taxis, which are considerably more expensive, but have a legal seating capacity of four passengers and provide a safer, more comfortable and direct travelling experience (Agyemang 2015). While shared taxis run along fixed routes (similar to tro-tros), chartered taxis (known locally as 'dropping') pick up and drop off in accordance to customer requests. The former operate with fixed rates whilst the latter fares are negotiable (taxis are never metered). Similar to tro-tro operators, the majority of taxi operators are members of GPRTU, hence the union controls 80 percent of Ghana's passenger and freight movement (Abane 2011).

An emerging form of public transportation in Accra that has thus far remained beyond both government and union regulation, and is practised in contravention of the existing transport legal regime, is the operation of motorcycles by male youth for commercial services called okada (Oteng-Ababio \& Agyemang 2012). The majority of okada drivers are based in the $\mathrm{CBD}$, particularly in the streets/open spaces near transport terminals or markets, though some operate close to key taxi and tro-tro terminals throughout Accra. They are becoming an important form of transport in newly developing peripheral areas where shared taxis and tro-tros are limited. All three modes of 'public' transport (tro-tro, taxi and okada) function both as sources of livelihood for their drivers and owners while simultaneously supporting the conduct of other residents' livelihood activities.

Few studies have considered the links between transport and livelihoods in Accra (exceptions being Grieco et al. 1996 and Turner \& Kwakye 1996), and none that we are aware of have been conducted in the past 20 years during which the transport system has evolved as outlined above. Drawing on research conducted in Accra and elsewhere, Fouracre et al. (2006, p. 329) have argued that traditional quantitative approaches to transport planning 'should be complemented by a better understanding of household activity patterns, and of the effects and implications of travel on livelihoods'. This is the focus of the 
rest of this paper, which draws on primary research conducted in residential areas of Accra to explore the links between livelihoods, mobility and transport.

\section{Methodology}

A qualitative approach was adopted in this research because it is particularly adept at obtaining data capable of furthering an understanding of the 'sets of meanings which people use to make sense of their world and their behaviour within it' (Cohen et al. 2011, p.9), in this case the intricacies of urban residents' mobility and livelihood strategies. Four residential areas were selected across the city to cover a variety of settlement types including older and newer areas, differing locations within the city, and differing types of population movement (see Table 1 and Figure 1). From October 2013 to January 2014, semi-structured interviews and focus group discussions were conducted in each residential area.

\begin{tabular}{|l|l|l|l|l|l|}
\hline Settlement & $\begin{array}{c}\text { Data } \\
\text { collected }\end{array}$ & \multicolumn{1}{|c|}{ History } & Location & Income Level & $\begin{array}{l}\text { Population } \\
\text { Change }\end{array}$ \\
\hline $\begin{array}{l}\text { Ashale } \\
\text { Botwe }\end{array}$ & $\begin{array}{l}\text { January } \\
2014\end{array}$ & $\begin{array}{l}\text { Indigenous core } \\
\text { growing rapidly since } \\
\text { 1990s }\end{array}$ & $\begin{array}{l}\text { North } \\
\text { East } \\
\text { (Peri- } \\
\text { urban) }\end{array}$ & $\begin{array}{l}\text { Low/middle/high } \\
\text { income }\end{array}$ & $\begin{array}{l}\text { Growing } \\
\text { rapidly }\end{array}$ \\
\hline Gbawe & $\begin{array}{l}\text { October } \\
2013\end{array}$ & $\begin{array}{l}\text { Indigenous core } \\
\text { growing rapidly since } \\
\text { 1990s }\end{array}$ & $\begin{array}{l}\text { West } \\
\text { (Peri- } \\
\text { urban) }\end{array}$ & $\begin{array}{l}\text { Low/middle/high } \\
\text { income }\end{array}$ & $\begin{array}{l}\text { Growing } \\
\text { rapidly }\end{array}$ \\
\hline $\begin{array}{l}\text { Korle- } \\
\text { Gonno }\end{array}$ & $\begin{array}{l}\text { October } \\
2013\end{array}$ & $\begin{array}{l}\text { Indigenous/traditional } \\
\text { settlement }\end{array}$ & $\begin{array}{l}\text { Western } \\
\text { edge of } \\
\text { centre }\end{array}$ & Low income & $\begin{array}{l}\text { Stable } \\
\text { population } \\
\text { size but } \\
\text { movement } \\
\text { in and out. }\end{array}$ \\
\hline New Town & $\begin{array}{l}\text { October } \\
2013\end{array}$ & $\begin{array}{l}\text { Migrant settlement } \\
\text { established 1940s }\end{array}$ & $\begin{array}{l}\text { Northern } \\
\text { edge of } \\
\text { centre }\end{array}$ & $\begin{array}{l}\text { Low/middle } \\
\text { income }\end{array}$ & $\begin{array}{l}\text { Shrinking as } \\
\text { residential } \\
\text { properties } \\
\text { are being } \\
\text { converted to } \\
\text { commercial. }\end{array}$ \\
\hline
\end{tabular}

Table 1: Overview of selected settlements

Altogether 118 semi-structured interviews were conducted with purposively selected individuals covering people of differing ages and both genders who were engaged in a range of livelihood activities. The majority of interviews lasted 30-45 minutes, although on occasion took up to two hours when respondents were keen to talk for longer. Fourteen focus group discussions were conducted, with most groups comprising six to eight participants who were brought together by a local resource person. In order to ensure that the views of both genders and a range of ages were heard, attempts were made to ensure that discussions 
were held with the following groups: male youth, female youth, elderly males and elderly females. Participants in the focus group discussions with young people ranged from 18 to mid-thirties (in line with the definition of youth in a sub-Saharan Africa context), whilst those in the older focus group discussions were aged from their forties upwards. The focus group discussions lasted around 90 minutes. Both interview types were taped and subsequently transcribed verbatim. They were then analyzed using analytical and in vivo coding to identify categories and trends within the text material, and to build themes that connect the empirical findings to broader literature and concepts.

\section{Livelihoods, mobility and transport in Accra}

Much mobility in Accra takes place in relation to livelihood activities (Turner and Kwakye 1996; Grieco et al. 1996; Langevang \& Gough 2009). In this section, we explore the interrelationship between Accra's transport system, residents' mobility and their livelihoods. The discussion is structured around three key types of livelihoods that emerged during the data analysis: 1) home-based enterprises, 2) enterprise operators whose business is located elsewhere, and 3) itinerant workers. Whilst a few formal sector workers were encountered, their mobility lies outside of the scope of this paper and has been discussed elsewhere (see Abane 1993 and Amoh-Gyimah \& Aidoo 2013).

\subsection{Home-based enterprise operators}

Running a business from the home is a frequent livelihood activity in urban Ghana. Gough (2010) found that one-third of households ran a business from their home in Accra, Yankson (2000) reported that 49 percent of homes housed a business in Accra, and Sinai (2001) found that the corresponding figure for Kumasi was 24 percent. People choose to run a home-based enterprise for numerous reasons but, especially for women who make up the majority of home-based enterprise (HBE) operators, being able to combine an incomegenerating activity with household responsibilities is a major attraction. Even though their business location is also their residence, thereby avoiding the need to travel to work, homebased enterprise operators travel frequently for their work in order to obtain essential goods. They thus face numerous decisions regarding the mode, timing and cost of their journeys. Maame, for instance, is a 39 year-old food seller who lives on the outskirts of Accra in Gbawe. She explained how her day starts early: 
At 4 am I will prepare everything for my children to go to school and when it gets to around 4.30 am I will leave the chores behind for the eldest and I will go and bath and set out to the market [Agbogbloshie] to buy goods in order to go and sell. Yes before 5 strikes I will be gone by then. I go to the station to take tro-tro and I will go and buy the things and come back ... I pay porters to carry the goods to the station. Then from there I will arrange for a dropping [chartered taxi] home ... Some drivers charge 20 cedis, others too charge 15. It all depends on the goods you are bringing. If they [the goods] are plenty they will charge you higher but if less they will charge you lower price. If the government increases fuel prices they will also charge higher.

The details that Maame provides regarding when she makes use of tro-tros, and the costs associated with transporting her goods from the market to her home and place of work, are illustrative of the working practices and expenses HBE operators' incur. Like others moving around the city, she engages in fierce price negotiation regarding taxi fares and even the price paid to a porter to carry her goods from the market, though these amounts are considerably lower. Negotiating prices plays an important role in residents' ability to navigate the city's transport system effectively, which is learnt through experience and interactions with others. The accumulation of these experiences and interactions between transport users and providers gives rise to a 'common sense' pool of local knowledge open to contribution and use, which reflects a broader trend in urban African environments whereby everyday transactions are subject to negotiation (Simone 2001). Thus the strongest negotiators, be it those providing or using the mode of transport, make the greatest profit. Similarly, Ato, a 33 year old carpenter who lives on the outskirts of Accra in Ashale Botwe, described how when going to buy materials he too travels into the city centre by tro-tro early in the morning and returns home in a taxi. Despite the queues being longest and the traffic heaviest at this time, he explained that he has to travel then because 'In the afternoon people don't go to town so the vehicles too stay there [in town] and don't come back. But in the evening since people have closed from work they [vehicles] come back [to Ashale Botwe]'. Ato's case demonstrates how the common practice of leaving in the early morning is linked to the tro-tro strategy of 'fill and run', i.e. a tro-tro will only leave a station once it is full so the driver can get the maximum number of fares for the cost of the fuel. Consequently, waiting times vary according to the time of day and it can actually be easier to board a tro-tro during peak hours, despite the long queues, because they fill up sooner. The severe traffic jams in peak hours are thus a by-product of the way livelihood strategies related to the practice of 'fill and run' feed into and reproduce the functional interaction between the periphery and key commercial hubs located in the centre, which is a legacy of colonial and postcolonial modernist urban planning. 
Living closer to the centre of Accra in Accra New Town, Emma (aged 34) makes and sells the local food, banku (a mixture of water, fermented corn and cassava dough), together with fish from her home. Previously Emma also fried and sold yams but now that she is responsible for taking her children to school she can no longer get to the market at Agbogbloshie early in the morning for supplies. Whilst she can walk to buy the fish she requires, she travels into the centre of Accra by tro-tro to buy the maize and returns with her goods in a taxi. Despite tro-tros passing close to her home, like most residents of Accra New Town she walks to the nearest tro-tro station in order to board because otherwise the bus is likely to be full. This lengthens the time she spends away from her business, and potentially costs her sales if she cannot find someone to watch the store in her absence, thus providing another example of how 'fill and run' impacts residents' livelihoods. Additionally, Emma, Maame and Ato's cases illustrate how patriarchal norms shape mobility. Unlike the two females, Ato does not have to structure his work related movements around household responsibilities. This resonates with wider debates regarding mobility in Ghana; as Langevang and Gough (2009) also found in relation to young people in Accra, men are generally more able to move spontaneously whereas women navigate the city in more deliberate and predetermined ways restricted by family responsibilities and expectations.

\subsection{Enterprise operators with a business located elsewhere}

With formal sector jobs being limited, around 80 percent of Ghana's population is estimated to work in the informal sector. Entrepreneurship levels are amongst the highest in the world and, exceptionally, more women engage in entrepreneurial activities than men (Langevang et al. 2015), with women in Ghana having played a central role in trading for centuries. Participants who operated a business outside of their home stressed that finding an affordable location is a real challenge. Interestingly, these residents highlighted that they placed far more emphasis on the location of their business in relation to potential customers, than on their own ability to reach the location. This was particularly noticeable amongst residents with businesses located in peripheral areas, such as Gbawe and Ashale Botwe, who explained that while rents are cheaper in the city's outskirts, this is offset by concerns about how others perceive the accessibility of their business location. These concerns are not just tied to the physical distance of their business from other parts of the city, but are also connected to perceptions of the terrain to be crossed including muddy, dusty and poor quality roads etc.

Concerns about how potential customers will perceive a business location results in many enterprise owners selecting premises that they believe their patrons will be able to access easily, which can lead to business operators having considerable journey times themselves 
in order to reach their places of work. Once there, however, they try to reduce the extent that they have to move around in relation to obtaining goods and reaching customers, at times drawing on networks of close relatives and friends to secure goods, or calling suppliers to reserve goods before sending a trusted taxi driver to collect the supplies on their behalf, paying for the goods using a mobile money platform. Importantly, an individual's ability to minimize their need to move by passing on the burden of navigating the transport system onto another person depends on where their business is located and their financial status, as well as building up connections and establishing trust with other individuals.

Adjoa (aged 40), who lives in Korle Gonno and trades in women's second-hand clothing, provides an illuminating example of the relationship between mobility and business location. Previously, she used to walk around the neighbourhood selling items but now she trades from a specific spot at Tema station three days a week on market days, which she finds much less tiring. She buys the second-hand clothing from the market in Kantamanto on nonmarket days, and has the clothes delivered to her on market days for a fee. This saves her having to carry the goods around the city and worrying about where she will store them, however, such agreements are only possible where a degree of trust has been forged between individuals. By locating herself at Tema station on market days where many people are passing by, Adjoa is able to harness the mobility of others rather than move around herself to sell. This strategy is not without its problems, since sellers compete over space with the tro-tro drivers, as she explained:

It is not good but we don't have anywhere else to move to. The drivers there can get angry at any time and when they do, they park their cars at where we are doing the market. You will have to talk lengthy before they will pay heed to you.

The more established business people can better dictate the terms of their movement, which has also been facilitated by the widespread use of mobile phones (see Porter 2012). For example, Josie (aged 32), who lives in Korle Gonno but works in Accra New Town where she trades in provisions, emphasized how:

Now I can't live without my phone because I use it for my business. I'm a trader so my customers call me. Supposing someone needs goods they call me on my phone for supply... You see there are so many things we would have had to do using transport but the phone allows me to do that without being physically present. I ask that the things be brought to me to sell.

Although new technology, including mobile phones, has changed how and when people move in relation to running their business, not everybody has the financial resources or 
business networks to be able to conduct operations in this way. Bernice (aged 37) noted that although she can now call to check that a supplier has the goods she requires, which allows her to negotiate the terms of her mobility and prevent wasted journeys, she still has to travel either from her home in Dansoman or her cosmetics store in Korle Gonno to Makola market in the centre of Accra to collect the goods. She always travels to the market by tro-tro, yet she returns either by tro-tro or in a shared taxi, despite the latter option costing her five times the price of a tro-tro. She explained how her decision 'depends on the body, how tired I become.' This is significant because, as Pirie (2009b, p.9) argues, although often taken for granted amidst contemporary narratives of effortless travel linked to technological improvements, there remain places in the world where "consideration of the bodily energy required to move' affects how, where and when people move. A resident's choice of transport mode is, therefore, not only closely connected to their wealth (see Kwakye et al. 1997), but also to their physical state and the bodily energy associated with different ways of moving. This has implications for the environment because the lack of non-road based modes discussed above means that for the foreseeable future, 'comfortable' travel will be synonymous with motor vehicles.

In several cases, travel in relation to running a business in Accra extends beyond the boundaries of the city and even outside of Ghana, particularly amongst business owners in Accra New Town's busy commercial district, which has historically served as a destination for migrants. Dinah (aged 34), for example, is a Ghanaian female trader in fabric and clothing materials who lives on the outskirts of the city in Kwabenya but runs a store in Accra New Town. Although she is a single mother with two children, she frequently travels by bus to Togo to buy goods for her business, with a round trip costing 10-15 cedis. As WrigleyAsante (2013) has demonstrated, cross-border travel of this nature by unaccompanied women does not come without its own physical and psychological challenges. Nevertheless, this case highlights how inter-urban and even international travel to Togo (where import duties are lower) to purchase goods in bulk can work out cheaper and be more time efficient than making frequent intra-urban journeys. Such travel, however, is tied to purchasing power and thus wealth. Poorer business owners are unable to adopt this approach, resulting in them having to make shorter, more frequent journeys and hence spend more of their income on travel.

\subsection{Itinerant workers}

Selling while on the move, referred to as 'street hawking', is common in Accra. Such itinerant workers provide a wide variety of low-cost goods to urban residents, while also being subjected to vehement criticism for congesting the streets. Different types of street hawkers 
have differing levels of mobility, hence they use the transport system in differing ways. Most are reliant on tro-tros and shared taxis for collecting the goods they sell, whilst some use the frequent traffic jams in certain parts of the city to their advantage by targetting customers stuck in the traffic (Asiedu and Agyei-Mensah 2008; Amankwaa 2015). Ironically, women such as Joy (aged 20), who lives in Ashale Botwe but sells sachet water on the roadside along one of the major routes in the centre of Accra, complained that the same traffic jams that provide her with customers also make her late when she is trying to get somewhere.

Rising transport costs was also raised by these workers, especially in the focus group discussions with female youth who noted how, as they often have to take their children with them when travelling, they have to pay their children's fares on top of their own. Moreover, itinerant workers in general appear to feel the impact of fluctuations in transport related costs and unsuccessful price negotiations more keenly than other types of workers. As their financial situation is often predicated on fine margins and the generation of small profits, many itinerant workers are unable to buy in bulk and have to make frequent journeys to collect supplies. Kwesi (aged 38) and Evans (aged 28) are both itinerant second-hand shoe sellers. While Kwesi, who lives in Accra New Town, purchases shoes in central Accra to sell on a daily basis, Evans, who lives further from the centre in Ashale Botwe, does so about three times a week. They rise early in an attempt to avoid long tro-tro queues at the market and, with their intimate knowledge of the transport system, at times take a tro-tro to a nearby neighbourhood then walk to avoid traffic jams.

Interestingly, in the absence of formal timetables, like many other itinerant workers, Kwesi and Evans construct their own innate timetables to produce a temporal structure to their movement around the city that entails a sense of order and routine. For both of them, walking while selling is fundamental to their livelihoods and allows them to keep one step ahead of law enforcement. As Kwesi explained, 'I go to distant places because when you sell on the streets you will be arrested. I walk when I am selling. So when someone sees the goods and he likes it then he buys it'. While he would prefer to be stationary, with a fixed place to sell his goods, at present being sedentary is a risky strategy unless he can identify a space he perceives as safe. Evans' experience indicates the problem itinerant sellers can face when stopping: 'I laid my goods on the road side. The security men threw our things away yesterday. They are giving us a big problem'.

As Kwesi and Evans have become known in the areas where they sell, some customers now ring to them requesting certain products that they then deliver. For other itinerant sellers, receiving orders by phone is an even more central aspect of their livelihood. Jacob (aged 37), who deals in vehicle spare parts, indicated that 'Sometimes I call them just to alert them 
[customers] that I am still around ... [so my] mobile phone is very important'. As his livelihood requires him to stay responsive to the sudden requests of his customers, his movement is often spontaneous, like others in the supply business. Living in Korle Gonno with its central location and good transport links to other parts of the city is ideal for Jacob. He uses a range of transport types depending on the reason for his journey, the time of day and his pocket:

I don't have a timetable for myself, it is my customers who keep me moving...I use a motorbike but sometimes when the supply is huge and the motorbike can't carry [it all] then I have to hire a taxi. I don't have money for a taxi now and I can't hire a taxi for the whole day, so even if it will take me 3 or 4 hours to supply, maybe 10 packets of goods by motorbike, I will do that because that is manageable for now.

The use of private motorbikes and okadas is most widespread in the central areas of Accra because they offer a way to circumnavigate the traffic induced by the city's vehicle dependency and flawed infrastructural development. This form of transport has clear gender and age dimensions, however, with both the drivers and passengers being mainly young men, further highlighting how not all means of transport are accessible to all urban residents. Fittingly, this demonstrates how an empirical and analytical approach that engages with people's livelihood strategies is well suited to examining how effective a transport system is at connecting spatially separated locations, and the extent to which a particular individual is able to make use of the transport system at their disposal. As noted by Porter (1997), understanding the relationship between these two issues is fundamental to creating a better understanding of mobility.

\section{Conclusions}

Drawing on qualitative research, this paper has illustrated the textured mobility of urban residents pursuing different categories of livelihood activities, and how they utilize the various modes of transport within Accra. Despite political, infrastructural and technological change, there is a remarkable consistency with the behaviour and narratives of Grieco et al.'s (1996) informants twenty years earlier, whereby 'traders both adapt their transport behaviour to the poor quality and low reliability of existing informal transport systems and creatively adapt the local informal public transport system to their business needs' (Grieco et al. 1996, p. 239). Whilst this is testament to the durability and adaptability of 'informal' entrepreneurial livelihoods, as shown here, the precise mobility strategies adopted are gendered and differ according to the reasons for a journey, the time of day, the body and one's pocket. 
The overarching argument that emerges from bringing a holistic approach that combines transport, mobility and livelihoods into conversation with the empirical findings is that conceptual frameworks such as the new mobility paradigm derived entirely based on conditions in the global North, are inherently limited, despite their implicit claims of global relevance. Indigenous, colonial and postcolonial urban legacies of modernist urban planning, including land-use zoning and residential segregation, have long embedded conditions that necessitate high levels of flexible mobility for the conduct of even precarious informal livelihoods. The Ghanaian examples deployed in this paper typify many low and lowermiddle income urban contexts worldwide. Ironically, while the mobilities turn emerged out of cultural geographical concerns at the apparent econocentrism of much prior research, the new mobilities paradigm itself neglects the essential livelihood dimensions underpinning much mobility and careful negotiation of complex urban transport systems. In this era of postcolonial and post-structural theorizing, it is essential to take due account of diverse conditions on the ground in different world regions. 


\section{References}

Abane, A.M., 2011. Travel behaviour in Ghana: empirical observations from four metropolitan areas. Journal of Transport Geography, 19(2), pp.313-322.

Abane, A.M., 1993. Mode choice for the journey to work among formal sector employees in Accra, Ghana. Journal of Transport Geography, 1 (4), pp.19-229

Agyemang, E., 2015. The bus rapid transit system in the Greater Accra Metropolitan Area, Ghana: Looking back to look forward. Norsk Geografisk Tidsskrift-Norwegian Journal of Geography, 69(1), pp.28-37.

Aidoo, E.N., Amoh-Gyimah, R. \& Ackaah, W., 2013. The effect of road and environmental characteristics on pedestrian hit-and-run accidents in Ghana. Accident Analysis \& Prevention, 53, pp.23-27.

Amankwaa, E.F. 2015. Women and men at the traffic lights: The (re)configuration and (re)gendering of street water vending in Ghana. GeoJournal DOI 10.1007/s10708015-9685-8

Amoh-Gyimah, R. \& Aidoo, E.N., 2013. Mode of transport to work by government employees in the Kumasi metropolis, Ghana. Journal of Transport Geography, 31, pp.35-43.

Amponsah, F. Turner, J. Grieco, M. Kwablah, A. Guitnik, P. 1996. Commercial Use of Nonmotorized Transport: Evidence from Accra, Ghana. Transportation Research Record: Journal of the Transportation Research Board, 1563(-1), pp.1-7.

Armah, F.A., Yawson, D.O. \& Pappoe, A.A., 2010. A systems dynamics approach to explore traffic congestion and air pollution link in the city of Accra, Ghana. Sustainability, 2(1), pp.252-265.

Cohen, L., Manion, L. \& Morrison, K., 2011. Research methods in education 7th ed., Routledge.

De Bruijn, M., van Dijk, R.A. \& Foeken, D., 2001. Mobile Africa: changing patterns of movement in Africa and beyond, Brill.

De Haan, L. \& Zoomers, A., 2005. Exploring the frontier of livelihoods research. Development and Change, 36(1), pp.27-47.

Dinye, R.D., 2012. Prospects and issues of railway infrastructure and development in Ghana. Journal of Construction Project Management and Innovation, 2(1), pp.259-284.

Edward, T., 1996. Transport and survival strategies in a developing economy: case evidence from Accra, Ghana. Journal of Transport Geography, 4(3), pp.161-168.

Fields, G.S., 1975. Rural-urban migration, urban unemployment and underemployment, and job-search activity in LDCs. Journal of development economics, 2(2), pp.165-187.

Finn, B., 2008. Market role and regulation of extensive urban minibus services as large bus service capacity is restored-Case studies from Ghana, Georgia and Kazakhstan. Research in Transportation Economics, 22(1), pp.118-125. 
Finn, B., Arthur, B.A. \& Gyamera, S., 2009. New regulatory framework for urban passenger transport in Ghanian cities. In 11th Conference on competition and ownership in land passenger transport. Delft University of Technology, the Netherlands, pp. 1-14. Available at: http://prijipati.library.usyd.edu.au/bitstream/2123/6026/1/706\%20087\%202009\%2008\%2001\%20Finn\%20New\%20Regulatory\%20Framework \%20in\%20Ghana.pdf.

Fouracre, P.R. Kwakye, E.A. Okyere, J.N. Silcock, D.T., 1994. Public transport in Ghanaian cities-a case of union power. Transport reviews, 14(1), pp.45-61.

Gough, K.V., 2010. Continuity and adaptability of home-based enterprises: A longitudinal study from Accra, Ghana. International Development Planning Review, 32(1), pp.4570.

Gough, K.V. \& Yankson, P., 2012. The environmental impact of rapid urbanization in the peri-urban area of Accra, Ghana. Geografisk Tidsskrift-Danish Journal of Geography, 99.

Grieco, M., Apt, N.A. \& Turner, J., 1996. At Christmas and on rainy days: transport, travel and the female traders of Accra, Avebury.

King, B., 2011. Spatialising livelihoods: resource access and livelihood spaces in South Africa. Transactions of the Institute of British Geographers, 36(2), pp.297-313.

Kwakye, E.A. \& Fouracre, P.R., 1998. The urban transport policy reform in Ghana. In Urban Transport Policy: A Sustainable Development Tool. Proceedings of CODATU VIII Conference.

Langevang, T. \& Gough, K.V., 2009. Surviving through movement: the mobility of urban youth in Ghana. Social \& Cultural Geography, 10(7), pp.741-756.

Lombard, J. \& Ninot, O., 2010. Editorial: Mobiles des Suds, mobiles au Sud. Espace Populations Sociétés. (2010/2-3), pp. 155-165

Mabogunje, A.L., 1990. Urban planning and the post-colonial state in Africa: a research overview. African Studies Review, 33(02), pp.121-203.

Møller-Jensen, L., Kofie, R.Y. \& Allotey, A.N., 2012. Measuring accessibility and congestion in Accra. Norsk Geografisk Tidsskrift-Norwegian Journal of Geography, 66(1), pp.5260.

Obeng-Odoom, F., 2010. Drive left, look right: the political economy of urban transport in Ghana. International Journal of Urban Sustainable Development, 1(1-2), pp.33-48.

Obeng-Odoom, F., 2013. Governance for pro-poor urban development: Lessons from Ghana, Routledge.

Oswin, N. \& Yeoh, B.S., 2010. Introduction: mobile city Singapore. Mobilities, 5(2), pp.167175.

Oteng-Ababio, M. \& Agyemang, E., 2012. Virtue out of necessity? Urbanisation, urban growth and Okada services in Accra, Ghana. Journal of Geography and Geology, $4(1)$, p.p148. 
Pirie, G.H., 2009a. Virtuous mobility: Moralising vs measuring geographical mobility in Africa. Afrika Focus, 22(1).

Pirie, G.H., 2009b. Distance. In R. Kitchin \& N. Thrift, eds. International Encyclopedia of Human Geography. Oxford: Elsevier, pp. 242-251. Available at: doi:10.1016/B978008044910-4.00265-0.

Porter, G. Hampshire, K., Abane, A.,Munthali, A., Robson, E.,Tanle., A., 2012. Child porterage and Africa's transport gap: Evidence from Ghana, Malawi and South Africa. World Development, 40(10), pp.2136-2154.

Porter, G., 2012. Mobile Phones, Livelihoods and the Poor in Sub-Saharan Africa: Review and Prospect. Geography Compass, 6(5), pp.241-259.

Porter, G., 1997. Mobility and Inequality in Rural Nigeria: The Case of Off-Road Communities. Tijdschrift voor economische en sociale geografie, 88(1), pp.65-76.

Rigg, J., 2007. Moving lives: migration and livelihoods in the Lao PDR. Population, Space and Place, 13(3), pp.163-178.

Rigg, J. \& Salamanca, A., 2011. Connecting Lives, Living, and Location: Mobility and Spatial Signatures in Northeast Thailand, 1982-2009. Critical Asian Studies, 43(4), pp.551575.

Shaw, J. \& Hesse, M., 2010. Transport, geography and the "new" mobilities. Transactions of the Institute of British Geographers, 35(3), pp.305-312.

Sheller, M. \& Urry, J., 2006. Mobile technologies of the city, Taylor \& Francis.

Simon, D., 1986. Regional Inequality, Migration and Development: The Case of Zimbabwe. Tijdschrift voor economische en sociale geografie, 77(1), pp.7-17.

Simone, A.M., 2001. Between Ghetto and Globe: Remaking Urban Life in Africa. In A. Tostensen, I. Tvedten, \& M. Vaa, eds. Associational Life in African Cities: Popular Responses to the Urban Crisis. Elanders Gotab, pp. 46-64.

Sinai, I., 2001. Moving or improving: housing adjustment choice in Kumasi, Ghana. Housing Studies, 16(1), pp.97-114.

Skelton, T. \& Gough, K.V., 2013. Introduction: Young people's im/mobile urban geographies. Urban Studies, 50(3), pp.455-466.

Wrigley-Asante, C., 2013. Survival or escaping poverty: The perspectives of poverty and well-being among Ghanaian women in cross-border trading. Journal of Gender Studies, 22(3), pp.320-334

Yankson, P.W.K., 2000. Houses and residential neighbourhoods as work places in urban areas: the case of selected low income residential areas in greater Accra metropolitan area (GAMA), Ghana. Singapore Journal of Tropical Geography, 21(2), pp.200-214. 